\title{
Democratization in Africa: the development condition revisited
}

\section{Democratização em África: a condição de desenvolvimento revisitada}

\author{
Manuel Couret Branco, \\ University of Évora, Portugal
}

\begin{abstract}
In the middle of the twentieth century S.M. Lipset sustained that various indicators of economic development were higher in democratic countries than in authoritarian ones, suggesting that development was a condition to democracy. More recently, though, several authors have shown that there is no strong empirical evidence confirming development as a condition to democracy, suggesting in turn that the economic is not as important in democratization as it seemed in the 1950s. Despite this fact, there are some clues that indicate that economic factors do play an important role in democratization, but in a way different than that proposed by Lipset. In this article a revision of literature on some economic obstacles to democratization in Africa is carried out, its main conclusion being that underdevelopment decisively contributes to the difficulties many African countries experience in democratizing and consolidating democracy. One should not mistake underdevelopment with un-development though, the latter being the mere absence or delay in development and the former a specific supporting role given to developing countries within the global development process. The article's general conclusion, therefore, is that democratic development is not a question of getting richer, i.e. intensifying the development model, as much as of reforming this same model.
\end{abstract}

Keywords-Democratization, Africa, Democracy, Development condition.

Resumo-Nos meados do século XX, S.M. Lipset afirma que vários indicadores de desenvolvimento económico são mais altos em países democráticos do que em países autoritários, sugerindo que o desenvolvimento é uma condição para a democracia. Mais recentemente, vários autores sustentam que não existem evidências empíricas que confirmem o desenvolvimento como condição para a democracia, sugerindo, por sua vez, que a economia não é tão importante na democratização como aparentava ser durante a década de 50. Apesar disso, existem algumas evidências que indicam que os fatores económicos desempenham um papel importante na democratização, mas de forma diferente da proposta por Lipset. Neste artigo é feita uma revisão da literatura sobre alguns obstáculos económicos à democratização na África, e a sua principal conclusão é que o subdesenvolvimento contribui decisivamente para as dificuldades que muitos países africanos enfrentam na democratização e consolidação da democracia. Não se deve confundir subdesenvolvimento com des-desenvolvimento, sendo este último a mera ausência ou atraso no desenvolvimento e o primeiro um papel de apoio específico dado aos países em vias desenvolvimento no processo de desenvolvimento global. A conclusão geral do artigo, portanto, é que o desenvolvimento democrático não é uma questão de enriquecimento, ou seja, de intensificar o modelo de desenvolvimento, mas de reformar esse mesmo modelo.

Palavras-Chave-Democratização, África, Democracia, Condição de Desenvolvimento.

Submitted-28-05-2019. Accepted-03-02-2020. 


\section{Introduction}

$\bigcirc$ OING on what he called the election related $\checkmark$ meltdowns in Zimbabwe and Kenya in 2008, Edmund Sanders, a journalist at the Los Angeles Times, said that, according to experts, one of the reasons for Africa's democratic fragility was worsening poverty, conveying the somewhat well established idea that there is a development condition to democracy (Sanders 2008). About half a century ago, reflecting on poverty and its terrible consequences for the majority of India's population, French ethnologist C. Lévi-Strauss also expressed his scepticism concerning the odds of the Indian citizen reaching freedom in the way western culture and thought represented it. For him, something as simple as a dignifying material existence was much more meaningful than formal democratic institutions (Lévi-Strauss 1984). He added that:

Freedom is neither a legal invention nor a philosophical jewel property of civilizations worthier than others because only they would possess the ability to produce and preserve it. It is the result of an objective relation between the individual and the space he inhabits, between the consumer and the resources available to him (...) much ingenuity and deceitfulness would have to be disclosed in order to believe that men choose their beliefs regardless of their condition. Political systems are far from determining patterns of social existence, patterns of existence give sense to the ideologies which express them, rather (...). (Lévi-Strauss 1984, 169)

Around the same time S. M. Lipset was one of the first social researchers to establish precise economic conditions to the democratization process (Lipset 1959). He asserted that various indicators of economic development, such as average wealth, degree of industrialization and urbanization and education levels were higher in democratic countries than in authoritarian ones, suggesting that development could stand as a condition to democratization. In other words the absence of development would apparently hinder

- Manuel Couret Branco, Full Professor of the Department of Economics, University of Évora, Portugal.

E-mail:mbranco@uevora.pt

DOI:http://dx.doi.org/10.21814/perspectivas.2506 democracy. Regarding wealth, B. Ndulu and S. O'Connell tested the hypothesis for Africa some twenty years ago and found that countries that, at their independence, adopted the multi-party system, started richer than those that opted for various degrees of authoritarianism, a fact which would support the hypothesis' credibility (Ndulo and O'Connel 1999).

In addition, A. Przeworski and others sustain that beyond the threshold of 6005 dollars per head no democracy has ever been overthrown, whereas the life expectancy of a democracy below the average income of 1000 dollars per head is only six years (Przeworski et al. 2000). The arguments set forward to justify the relevance of wealth for democratization suggest that, firstly, when income is high, or economic growth rapid (Dahl 2000), redistributive conflicts are less intense and, therefore their resolution can happen under the rule of law rather than through the use of force; secondly high income allows the formation of an important middle class, and, thirdly, it can lead to better education.

Low income could, therefore, explain the poor records concerning democratization in African countries, of which only about $20 \%$ are considered fully democratic (Freedom House 2007). Nevertheless, things are not as simple as they could apparently seem. First of all, several empirical studies seem to show that there is no relationship between the level of income per head and democracy. J. Robinson, for instance, finds that if income and democracy are correlated it is because the same features of a society simultaneously determine how prosperous and how democratic this one is (Robinson 2006). In the above-mentioned study A. Przeworski and others, although sustaining that wealth has an effect on the survival rate of democracy, find, nevertheless, that it seems to have no effect on the emergence rate of democracy (Przeworski et al. 2000). Other studies reach this same conclusion, which is that there is no linkage between wealth and democracy (see Acemoglu et al. 2005). The fact that one can find all sorts of combinations between income levels or growth records and the democratic or authoritarian nature of the political regime reinforces the conclusion that wealth is neither a decisive obstacle nor a precondition to democratization (see UNDP 2020; 
Leftwich 2000).

As a matter of fact, more than an argument to explain the lack in democratization, it seems that insufficient wealth has been used by many autocratic governments to justify their unwillingness in engaging on a democratic transition, and ensuring poor people political as much as economic and social rights. In 1968, for example, slightly after a successful military coup, an Argentinean government official told A.O. Hirschman that only once the country had attained economic stability and a certain level of economic growth would it be ready for the reinstatement of civil liberties (Hirschman 1988), a typical reasoning of the Latin American desarrollismo of the 1950s that presupposed democracy to be a consequence of economic development, a process which S. Amin critically classified as a mere modernization of dictatorship, leading only to the perpetuation of repression (Amin 1989).

These arguments would tend to sustain the idea that the economic influence on the process of democratization is not as important as Lipset's path-breaking work would suggest. Despite the fact that the level of income does not seem to influence democratization it is slightly hasty to conclude that economic factors are irrelevant in such a process, though. In the following pages we will review some literature about democracy in Africa that shows that, on the contrary, economic factors could be decisive, but in a way different than that suggested by the Lipset hypothesis. The purpose of this paper is to go beyond wealth and economic growth and to explore issues that characterize more complex definitions of development and underdevelopment such as inequality, economic structure, culture, economic globalization and colonial heritage.

\section{Inequality, impoverishment and Democracy}

By declaring in the beginning of the 1990s that, in Africa, there cannot be democracy without the reduction of inequality, respect for the environment, and better access to education and health, R. Dumont, in a slightly, but significantly different registry, shares with Lipset the point of view according to which there is an economic conditionality to democratization (Dumont 1991). However, introducing inequality into the democratization equation, Dumont radically opts for a different perspective.

Indeed, if the impact of income on democracy is not very convincing, its distribution, on the contrary, would seem to gather broader consensus. The existence of a significant middle class was actually pointed out by S.M. Lipset (1959) as relevant to democracy and was supposed to result from the development process. Now, by definition, middle classes tend to be stronger, precisely, where income inequalities are low. B. BoutrosGhali, in his turn declares that 'one of the major impediments of democratic development resides in the serious inequalities that exist' (Boutros-Ghali 2003, 22). Indeed, some empirical evidences seem to have been found relating inequality and the lack of democracy, or in the other way around, the positive relationship between moderate or declining inequalities and democracy (Acemoglu 2003; Engerman and Sokolof 2002; Barro 1999; Przeworski et al. 1996), the main argument being that the gap between the rich and the poor, rendering distributive conflicts more acute, and creating a feeling of economic insecurity, would contribute to erode people's and leaders' adhesion to democracy (Fitoussi 2004). Furthermore, income distribution inequalities tend to be accompanied by inequalities in the access to other political resources, such as respect, status, information or knowledge resulting all in the political sub-representation of the poorest social groups (Dahl 2004; Engerman and Sokolof 2002).

If one looks at data concerning income distribution in Africa, the inequality argument does not seem very eloquent, though. Sub-Saharan Africa, for instance, presents an extreme diversity of figures concerning income distribution. Taking as a reference the Gini coefficient, which establishes the value 0 for a perfectly equal distribution and 1 for a perfectly unequal distribution, the most unequal distribution in the world can be found, exactly in Africa, in Namibia to be more precise, with 0.70 .

Unfortunately for the validity of the income inequality explanation for incipient democracy in Africa, Namibia is considered a full democratic country. So is Botswana with a Gini coefficient of 
0.63. On the other hand, countries like Rwanda and Ethiopia which are not yet fully democratic display respectively a Gini coefficient of 0.29 and 0.30 (UNDP 2004, 185-187). Of course one may question the accuracy of these figures for countries that have a notoriously weak production of statistics. Nevertheless, the questionable validity of the income inequality argument remains unanswered. In order to get a better explanation one should probably approach the inequality argument in a completely different manner.

As seen before the main argument sustaining the connection between inequality and democracy especially concerns the existence of redistributive conflicts (see Acemoglu and Robinson 2006). Thus, inequality would be detrimental to democracy insofar as the higher the inequality the higher the distributive conflicts. Therefore, it is essentially the existence of distributive conflicts that matter, not so much inequality. It is not too risky to admit that distributive conflicts are as bound to occur when income is unequally distributed as when income is declining or just stagnating. In this case African figures are more revealing. Indeed, between 1970 and 1998 real wages fell of more than 25\% (Hugon 2001, 64). Furthermore, whereas the growth rate of income per head in the developing world averaged $2.3 \%$ annually between 1975 and 2002, Sub-Saharan Africa saw its income per head decrease at an average annual rate of 0.8\% (UNDP 2004, 185-187).

Thus, if Botswana displays a high income inequality it also displays a high growth rate of per capita income, more precisely $5.1 \%$ annually between 1975 and 2002. Mauritius and Cape Verde, with respectively $4.6 \%$ and $3.0 \%$ are also good examples. On the other hand, Rwanda displayed a growth rate of $-0.6 \%$ for the same period. As a matter of fact, all democratic Sub-Saharan African countries displayed a growth rate higher than the sub-continent's average, and half of them displayed a positive growth rate. On the contrary, at least half of the non-democratic Sub-Saharan African countries displayed a growth rate below the sub-continent's average, and only two out of twelve grew positively, Côte D'Ivoire, Congo and Angola, with respectively, $-2.0 \%,-1.6 \%$ and $1.5 \%$, being the worst examples (UNDP 2004, 185187; Freedom House 2007). Therefore, it seems that impoverishment could constitute an obstacle to democratization more than just poverty or plain income inequality.

\section{Economic Structure and Democracy}

Economies in Africa have been historically dependent on the export of a scarce variety of natural resources or plantation crops. According to data released by UNCTAD for 2004, for instance, amongst the 39 African countries for which figures are available, $75 \%$ of export revenues depend on three or less commodities in 17 countries; 50 to $75 \%$ of these same export revenues depend on three commodities in 12 countries; and only in 10 countries do the three major export commodities represent less than $50 \%$ of export revenues (UNCTAD 2007). First, there is some evidence that economies with abundant natural resources have tended to grow less rapidly than natural-resourcescarce economies (Sachs and Warner 1995). As slow growth may negatively influence democratization as seen earlier, this characteristic of many African economies conditions the democratization process in an indirect way. Second, this particular economic structure can explain why elites in power resist to democratization.

A classical and institutionalist compromise theory considers institutional change to preferably occur when agents detaining power perceive the advantages of pursuing their private interests according to different rules of the game (Grindle 2001; Robinson 1998). Therefore, if rulers are so weakly inclined to democratize their countries it is because they are not interested in democratizing, or in other words because democratization goes against their best interests. An African autocrat, then, will rationally resist democracy if this means that, in the process, he or she will lose more than just political power (Robinson 1998). The crucial question, here, is why losing political power constitutes an attack on African rulers' economic interests.

The social and economic structures of many African countries.have shown a tendency to lead to loot-seeking activities (Collier and Gunning 1999). In other words, through monopoly, excessive taxation and corruption, rulers have had a relatively easy opportunity to gripe a considerable 
share of their countries' resources. This kind of appropriation of national income is clearly opposed to democratic, problem solving, distribution of national wealth, even more so when the ruling elites constitute a small group, the gains to an extractive strategy, a euphemism for loot, being closely related to the size of the ruling elite group (Acemoglu, Johnson, and Robinson 2001).

When the elite is scarce, each member can expect a larger piece of the pie and so, the smaller the elite group, and we could add the more unequal the income distribution, the greater the incentives to be extractive. Following the same line of thought, the greater the extractive character of the economy, the greater the risk for the elite's members of becoming political losers, that is to say, of losing their economic and social status if replaced in power, which, in turn, favours authoritarian strategies to keep that same power. Furthermore, this kind of economic structure does not favour the uprising of new elites that, along the lines of agency theory would engage in political struggle with the already installed elites and would end up forcing them to accept the democratic game (Mazo 2005).

It is not all too unexpected that this kind of economic structure incites rulers to keep the power. Indeed, with the notable exception of Botswana, most African countries that rely on natural resources are having more troubles either to democratize or to consolidate democracy than others. Angola, Nigeria, the Democratic Republic of Congo, Sierra Leone or Equatorial Guinea are good examples of this phenomenon. What can be more unexpected is that, in these circumstances, the population may receive the same incentives. Indeed, through free elections, people may be pushed to prefer keeping authoritarian rulers in office despite clearly condemning their behaviour. In a street interview on the occasion of the first pluralist elections in Mozambique, when asked to comment the performance of the party in office, the Frelimo, a citizen declared that it had spent its time robbing the people. Continuing with the interview, the journalist asked whom was he going to vote for. Much to the astonishment of the interviewer, he said that he was going to vote for the Frelimo. When the journalist confronted the citizen with the possible contradiction of his negative opinion about the Frelimo and his voting intentions, he simply answered that unlike its competitors, namely the Renamo, Frelimo had already done its share of robbing the people.

In fact, these contradictory incentives are not only characteristic of economies dependent on few natural resources or plantation crops. The overwhelming presence of the state in the economy, more frequent, precisely, in the case of economies dependent on natural resources such as oil, is also an important factor of a democratic deficit. R. Dahl shows how the economy in the America described by Tocqueville in 'Democracy in America', was based on highly decentralized individual farming, which gave few opportunities to the politicians to have access to the resources and, therefore, favoured a democratic development (Dahl 2000, 194). When, on the contrary, politicians have access to the nation's resources through government, it is harder to convince them of peacefully transferring power to rival political groups.

In many African countries, both the excessive specialization and alienating dependence from volatile external markets, whose effects on democracy have just been seen above, are essentially an historic resilience of European colonization, of the fact that colonizers were mainly interested in exploiting natural resources and exotic crops (Frank 1966, Jalée 1973; Amin 1973; Amin 1977). In turn, the fact that the colonial administration delegated the day to day running of the state to a small domestic elite (Acemoglu, Johnson, and Robinson 2001) as well as the low investment made on educating the native population, partly explains the existence, at the time of independence, of a small elite group, almost exclusively connected to either extractive activities or colonial administration.

After having taken control of the state, these elites received few incentives to change the institutions and consequently favoured the undemocratic and extractive institutions that prevailed in the colonial era (Acemoglu, Johnson, and Robinson 2001). A comparative study of Botswana and Lesotho provides an enlightening example on this subject. Despite sharing the same traditional ruling institutions in pre-colonial times and being culturally very close, Botswana evolved towards a democracy immediately after indepen- 
dence whereas Lesotho did it only since the 1990s. The reason for this divergence could be sought in the recent history of the two countries. The limited impact of colonial rule in Botswana, as compared to the experiences of many other nations in Africa, South America or the Caribbean, allowed the continuity of pre-colonial institutions and the elites that came to power after the independence were only partly members of the former administrative elite (Acemoglu, Johnson, and Robinson 2002, 23). The power, therefore, became essentially delegated. In Lesotho, on the contrary, the wars against the Boers and the fact that the British were much more intervenient undermined the traditional institutions and contributed to the centralization of political power in the hands of the colonial elites (Acemoglu, Johnson, and Robinson 2002, 29).

\section{The Political Economic Roots of the Relationship between Culture and Democracy}

There are mainly two approaches to the cultural classification of obstacles to democracy. The first approach deals with the impacts on democracy of the national, ethnic or religious differences within the geographical territory upon which the demos is established, and the second with the potentially more authoritarian or more democratic character of a society's political culture.

Regarding the first aspect of the cultural explanation of authoritarianism, there seems to be some generalized recognition that it is easier for a culturally homogenous country to democratize than for a country with deeply differentiated and conflictive subcultures (Dahl 2000; Bardhan 1999). Indeed, whenever there is strong ethnic diversity, political structures tend to be organized around ethnic groups rather than around interest groups. Therefore, whenever an election is called, it appears to be ethnic belonging or demographic vigour that is being balloted, rather than strategies outlined to enhance the public good. Furthermore, sympathizers of a particular culture frequently see their demands as questions of principle, too crucial to indulge in compromise, whereas the democratic resolution of political con- flicts necessarily needs negotiation, conciliation and compromise (Dahl 2000).

In addition, cultural pluralism seems incompatible with the necessity of building nations, considered one of the first steps to democracy, as democracy is inconceivable without some form of community inclusion and exclusion, which is necessarily enabled by the nation. To some extent this is the main reason why many African governments emerging from the independence processes used a considerable amount of their energy to repress any claim to difference, institutionalizing undemocratic governance as the only way to build their nations. The outcome was a vicious circle from which it seemed hard to escape. On the one hand, dictatorship was used to repress cultural differences and, on the other hand, the repression of cultural pluralism led to the exacerbation of this same cultural pluralism through clandestine forms, much more dangerous to the goal of national unity that repression was supposed to achieve (Amin 1989, 163).

Regarding the influence of political culture on democracy, the works of M. Weber (1958) and, later, G. Almond and S. Verba (1963), for example, opened the way to considering some cultures more fit to democracy than others. According to M. Weber the Protestant versus Catholic cultural fracture could explain the democratic preference of the former as opposed to the latter's authoritarian inclination. G. Almond and S. Verba, in turn, enhanced the role of mutual trust and tolerance of diversity. Splitting the world's society into survival and self-expression values, R. Inglehart adds more arguments to this cultural explanation of undemocratic governance.

He finds that cultural zones that share the self expression values, characterized, amongst other features, by tolerance and interpersonal trust, are more inclined to be democratic than the ones sharing survival values (Inglehart 2000, 80-97). In this respect the only African countries included in his survey, Ghana, Nigeria and South Africa, do not rate too bad. Nevertheless, if one conjugates this cultural aspect with the dichotomy traditional versus secular influence on society, these same African countries end up joining the group that rates the worst, as opposed to the more democratic countries where there are high levels 
of both self expression values and secular influence (Inglehart 2000, 85).

In a conference on globalization, science, culture and religions, held in Lisbon in October 2002, D. Etounga-Manguelle (2002), chairman of a Yaounde based company, adds another argument to the cultural explanation of authoritarianism declaring that among the African cultural features there is an excessive concentration of authority and power in one individual, who will often claim magical powers. The recent history of Africa gives indubitable examples of this excessively centralized manner, to say the least, of performing authority, but is this the demonstration we are looking for, that authoritarianism is a cultural feature? Indeed, on many occasions, while analyzing the cultural background of authoritarianism there is a tendency to isolate these features from the last centuries of Africa's history.

If one wants to look for, say, an African tradition of exercising authority, one should not forget the few hundred years of colonization and unequal development that have affected this continent. In order to get a more authentic view of tradition in these fields, one should probably have to study pre-colonial Africa. In doing so, the image of the despotic tradition in African ruling is not so striking. Where there were organized states the forms of government could be either centralized or more participative. One feature, though, seems present almost everywhere, the possibility of the people overthrowing the ruler in many different institutionalized ways (Davidson 1981; Ayittey 1992; Lacoste 1993).

However powerful are these cultural explanations, they do not succeed in excluding economic and political foundations. Regarding the argument consisting in blaming cultural diversity for authoritarian governance one must remember that the colonial administration is not only responsible for imprisoning cultural diversity by administratively designing the regions upon which the new nations were to be built regardless of their cultural profile, but also for inventing ethnical diversity itself (Branco 2006). Indeed, S. Amin declares impudently that the colonial administration has a determinant responsibility in the creation of the ethnic reality (Amin 1989, 151), G. Nkrumah (1998) sustains that the laws and the institutions inherited from the colonial powers were often designed to exploit ethnic, religious and linguistic differences within and between African states (Nkrumah 1998). Finally, B. Davidson, on tribalism - a ramification of ethnicity - declares that it is a convenient invention of the colonial period (Davidson 2000).

The purpose of this invention seems obvious: it intended to make the colonial administration of vast territories easier and cheaper, without the mobilization of a great number of Europeans who were not only scarce, in view of the enormous task, but also clearly ill adapted to the climatic conditions in the field, and thereby condemned to face high natural mortality rates (Acemoglu, Johnson, and Robinson 2001). J.S. Gallieni, a military commander and administrator in the French colonies, expressed this vision in a very clear fashion in 1899:

An officer who

manages to draw up an exact enough ethnographical map of the territory which he commands is very close to having it entirely pacified, soon followed by the organization most convenient for him (...) any political action in the colony has to consist in identifying and turning to advantage the useful local elements, in neutralizing and in destroying the non-useful local elements. (Ruscio 2008)

The invention of cultural differences also served the needs of the colonial rulers in the creation of labour reservoirs and the segmentation of labour along ethnic lines (Ishemo 2002, 2537). This does not mean that ethnic diversity only exists in Western minds. Ethnic diversity and ethnic conflict are facts of contemporary life. Our point is that this diversity was overestimated from the beginning and exacerbated with calculated action by the colonial administration.

The differentiation between Tutsis and Hutus in both Rwanda and Burundi, for example, is a perfect illustration of the artificial methods used to separate people more than any important feature, culture, language or history, did in the first place. Some say that, traditionally, the Tutsi minority was the ethnic group that dominated the Hutu majority, but we know very well today that the tale of the feudal Tutsi domination was made up by the Belgian colonization (Lacoste 1993, 747- 
748). Indeed, in order to control the territory, the Belgian administration relied on the Tutsi minority, invoking a fake ethnical and almost racialist distinction between a Bantu and a Hamite origin that gave the Tutsis an alleged touch of nobility to which Hutus could not aim. In other words, the Tutsis were considered whiter, or less black, than the Hutus. The colonization, then, established the Tutsis as the elite and, therefore, the administration in the pre-independence period, as much as after the independence, was monopolized by them creating as one could expect frustration and resentment among the Hutus.

The external influence of the colonizer seems also to be at the origin of the rise of many other ethnic groups such as the Bambara in Mali, or the Bete in Côte d'Ivoire (Lacoste 1993; Latouche 1986). In Madagascar, at the beginning of the twentieth century, the colonial administration artificially defined the existence of eighteen tribes and today people recognize themselves in this distinction, especially because the names that were given to the tribes were related to the physical characteristics of the territories they inhabited; Tefasy means those who come from the sands, Tanala, those coming from the forest, and so on (Rakotoarisoa 2002).

Ethnic conflicts can also be the result of other external interferences, besides the colonial adventure. According to Y. Lacoste many of today's ethnic conflicts in Africa have their origins in the slave trade (Lacoste 1993). From the eighth century until the nineteenth century, the Arabs first, and the Europeans later on, used some ethnic groups to capture slaves. A great deal of the actual ethnic conflicts would, therefore, be coincidental with the frontier between the predator and the predated groups within African population. Although slavery is a very old system, prior to European colonization, there is no doubt about the fact that the mass slave trade has an external origin, based on the labour demands of the economic systems of other colonized regions - the Americas by the Europeans, and the Mediterranean and the Middle East by the Arabs.

\section{Economic Globalization and Democ- racy}

I have argued elsewhere that economic globalization should be looked for in the dynamics of capitalism rather than in a balance of payments sheet (see Branco 2007). Indeed, economic globalization cannot be reduced neither to the mere dilatation of foreign trade nor to the acceleration of the mobility of productive factors. That is why when relating globalization to democratization in African countries, in addition to trade and specialization one also has to take into consideration such issues as external debt and structural adjustment.

First of all, the logic of boundless capitalist development is consensually conducive to the intensification of international trade and to its corollary, international specialization. Thus, reinforcing the formerly mentioned vicious dependency on natural resources, economic globalization can constitute an obstacle to democracy in many African countries. Indeed, not only this dependency has not been overcome, but other negative aspects, such as degradation of the terms of trade, were added to exacerbate this dependency. The evolution of the terms of trade has not been historically favourable to African countries and the situation seems to have grown worse over the last decade. As far as agriculture export commodities are concerned, in sub-Saharan Africa for example, the terms of trade index, base 100 in 1990, shrank from 185 in 1960 to 85 in 2000 (UNCTAD 2005). This not only affects the availability of means (i.e. the level of income), but also forces countries to insist on expanding their few foreign currency producing economic sectors, in other words it leads them into reinforcing specialization, and perpetuating an economic structure unfavourable to democracy.

The second item, the debt burden, and the consequent need to face international financial commitments, pushes African countries exactly in the same direction. The structural adjustment programs, for example, especially designed to ensure debt repayment, have forced these countries to adopt policies that have seriously affected the conditions for the surge and consolidation of democracy. Firstly, many African countries were obliged to overemphasize their commercial objec- 
tives at the expense of their social objectives. In consequence, not only the struggle against poverty and the effort to raise the level of education were slowdown, but the economy got more dependent than before on the export of natural resources as well (Mazur 2004, 61-71). Furthermore, adjustment programs were also responsible for increasingly unequal distribution of income (Leftwich 2000).

Structural adjustment programs could have played an important part in the democratization process, though. The emphasis put on the private sector was an important tool to counter-weigh the state, which was crucial to dismantle the loot seeking system mentioned above. Instead, it contributed mainly to empty the positive role of the state and for the private sector to call upon him the responsibility of curtailing human rights (Mazur 2004, 67). At last, the fact that these programs have been presented to African countries as the only alternative to conciliate financial orthodoxy and development did not leave, one must admit, much room for democratic debate.

\section{Conclusions}

From what has been said above it appears that difficulties endured by many African countries in democratizing can, indeed, partly have an economic explanation. But contrary to what the Lipset thesis seems to postulate it is not undevelopment, that is to say poor levels of development, as much as underdevelopment that could constitute an obstacle to democratization in Africa. Indeed, despite the family links, undevelopment and underdevelopment are not really twin concepts. Concerning the well being of populations, statistics portraying un-development and underdevelopment can roughly be the same, but these two concepts, nevertheless, refer to two very different phenomena. If rich countries have once been poor, as poor as poor countries are today, in other words undeveloped, they have never been underdeveloped as A.G. Frank has put bluntly (Frank 1966).

Underdevelopment, therefore, should not be mistaken with a mere absence or delay in development. Underdevelopment is not an absence, it is a presence; the presence of a particular form of development, of capitalist development one should add, that has also once been called dependent development (Frank 1966; dos Santos 1978; Cardoso and Faletto 1981). Underdevelopment, therefore, is not only characterized by low levels of income, industrialization, urbanization and education, it is also, and especially, characterized by impoverishment and strong inequalities, not only concerning income distribution but also access to means of production and to education and health, and by a handicapping history of colonial and neo-colonial domination which evolved to a particular and unequal insertion in the world economy, consubstantiated in an undiversified economy, predominantly directed to the export of primary goods, unequal distribution of international trade benefits and heavy external debt.

This brief overview of arguments concerning the economic obstacles standing before democratization shows that underdevelopment could, indeed, play an important role in fettering democracy in many African countries. This means that policies designed to promote democracy should not be directed to pulling out these countries from a merely delayed state of development by communicating greater spirit to their economic and social dynamics, but, on the contrary, to deliver them from that dynamics, from the underdevelopment model in which they have been historically trapped.

Therefore, as opposed to the actual trend, emphasis should, then, be placed on social rather than on commercial objectives, in other words on fighting poverty and reducing inequalities in national income distribution rather than on increasing no matter how this same income; on reorienting public expenditure to expanding human capabilities rather than on constricting the state in search of the marvellous freedom of the market; on institutional design innovation rather than on institutional transplantation and homogenization of cultural patterns; on looking for diversifying the sources of income rather than on overexploiting the traditional sources of this same income, compelled by the need to reimburse external debt; on searching for a more equitable global distribution of the benefits from international trade rather than on imposing world wide deregulation of trade 
and, last but not the least; on erasing external debt instead of multiplying conditional schemes that can only allow an homeopathic reduction of the debt burden and, therefore, secure the perpetuation of the status quo. In conclusion it seems that democratization in Africa does not demand diplomatic and economic pressure from western developed countries as much as building something close to a new global economic order.

\section{Acknowledgements}

This study was conducted at the Research Center in Political Science (UID/CPO/0758/2019), University of Évora, and was supported by the Portuguese Foundation for Science and Technology and the Portuguese Ministry of Education and Science through national funds.

\section{References}

[1] Acemoglu, Daron, Simon Johnson, James A. Robinson, and Pierre Yared. 2005. "Income and Democracy." American Economic Review 98(3): 808-842.

[2] Acemoglu, Daron. 2003. "The Form of Property Rights: Oligarchic vs. Democratic Societies." National Bureau of Economic Research (NBER) Working Paper no. $1003 \%$.

[3] Acemoglu, Daron, Simon Johnson, and James A. Robinson. 2002. "An African Success Story: Botswana." Centre for Economic Policy Research, Discussion Paper Series 3219.

[4] Acemoglu, Daron, Simon Johnson, and James A. Robinson. 2001. "The Colonial Origins of Comparative Development: An Empirical Investigation." The American Economic Review 91 (5): 1369-1401.

[5] Almond, Gabriel, and Sidney Verba. 1963. The Civic Culture. Princeton: Princeton University Press.

[6] Amin, Samir. 1989. La Faillite du Développement en Afrique et dans le Tiers Monde. Paris: L'Harmattan.

[7] Amin, Samir. 1973. Le Développement Inégal. Paris: Éditions Minuit.

[8] Amin, Samir. 1977. O Imperialismo e o Desenvolvimento Desigual. Lisboa: Edições Ulmeiro.

[9] Ayittey, Georges. 1992. "Les Blocages du Développement Africain." Afrique 2000: Revue Trimestrielle 12: 75-97.

[10] Barro, Robert J. 1999. "Determinants of Democracy." Journal of Political Economy 107(6): 158-183.

[11] Boutros-Ghali, Boutros. 2003. The Interaction Between Democracy and Development. Paris: UNESCO.

[12] Branco, Manuel C. 2007. "The Logic of Globalisation and Substantive Democracy." Economics Working Papers 2007/01, University of Évora.

[13] Branco, Manuel C. 2006. "Ethnicity, Democracy and Economic Development: a pluralist approach." In Ethics and the Market: Insights from Social Economics, edited by Betsy J. Clary, Wilfred Dolfsma, and Deborah M. Figart, 161-175. London: Routledge.

[14] Calderón, Fernando, and Alicia Szmuckler. 2004. "Political Culture and Development." In Culture and Public Action, edited by Vijayendra Rao, and Michael Walton Stanford, 281-306. California: Stanford University Press.

[15] Campos, Rui F, and Rafael Marques. 2005 Lundas: as Pedras da Morte. Lisbon: Fundação Mário Soares, Open Society Angola, Netherlands Institute for Southern Africa.

[16] Cardoso, Fernando Henrique, and Enzo Faletto. 1981. Dependência e Desenvolvimento na América Latina. ILPES: Santiago de Chile.

[17] Collier, Paul, and Jan Willem Gunning. 1999. "Why has Africa Grown Slowly." Journal of Economic Perspectives 13(3): 3-22.

[18] Dahl, Robert. 2000. Democracia. Lisbon: Temas e Debates.

[19] Davidson, Basil. (1992) 2000. O Fardo do Homem Negro. Porto: Campo das Letras.

[20] Davidson, Basil. 1981. À Descoberta do Passado de África. Lisbon: Sá da Costa.

[21] Dos Santos, Theotonio. 1978. Imperialismo y Dependencia. Mexico DF: Ediciones Era.

[22] Dumont, René. 1991. Démocratie pour l'Afrique. Paris: Seuil.

[23] Engerman, Stanley L., and Kenneth Sokolof. 2002. "Factor Endowments, Inequality, and Paths of Development among New World Economies." National Bureau of Economic Research (NBER) Working Paper no. 9259.

[24] Etounga-Manguelle, Daniel. 2002. "Globalization and The Conflict of Identities." Paper presented at the Conference on Globalization, Science, Culture and Religions. Lisbon: Fundação Calouste Gulbenkian, 15-16 October. 
[25] Fitoussi, Jean-Paul. 2004. La Démocratie et le Marché. Paris: Grasset.

[26] Frank, Andre Gunder. 1966. "The Development of Underdevelopment." Monthly Review 18(4): 17-31.

[27] Freedom House. 2007. "Map of Freedom 2007". http: / / www.freedomhouse.org/template.cfm?page=363\& year $=2007$ (Accessed November 2019).

[28] Grindle, Merilee. 2001. "In Quest of the Political: The Political Economy of Development Policymaking." In Frontiers of Development: The Future in Perspective, edited by Gerald M. Meier, and Joseph E. Stiglitz, 345-380. Washington: The World Bank.

[29] Haworth, Alan. 1994. Anti-libertarianism; markets, philosophy and myth. London: Routledge.

[30] Hirschman, Albert O. 1988. "La Confession d'un Dissident : Retour sur la Stratégie du Développement Économique." In Les Pionniers du Développement, edited by Gerald M. Meier, and Dudley Seers, 93-119. Paris: Economica.

[31] Huber, Evelyne, Dietrich Rueshmeyer, and John D. Stephens. 1993. "The Impact of Economic Development on Democracy." Journal of Economic Perspectives 7(3): 71-85.

[32] Hugon, Philippe. 2001. Économie de l'Afrique. Paris: La Découverte.

[33] Inglehart, Ronald. 2000. "Culture and Democracy." In Culture Matters: How Values Shape Human Progress, edited by Lawrence Harrison, and Samuel P. Huntington, 80-97. New York: Basic Books.

[34] Ishemo, Shubi. 2002. "Culture, Liberation and Development." In Development and Culture, edited by Deborah Eade, 25-37. Oxford: Oxfam.

[35] Jalée, Pierre. 1973. Le Pillage du Tiers Monde. Paris: Maspero.

[36] Lacoste, Yves (ed.). 1993. Dictionnaire de Géopolitique. Paris: Flammarion.

[37] Latouche, Serge. 1986. Faut-il refuser le développement. Paris: Presses Universitaires de France.

[38] Leftwich, Adrian. 2000. States of Development. Cambridge: Polity.

[39] Lévi-Strauss, Claude. (1955) 1984. Tristes Tropiques. Paris: Plon.

[40] Lipset, Seymore Martin. 1959. "The Social Requisites of Democracy: Economic Development and Political Legitimacy." American Political Science Review 53: 69-105.

[41] Mazo, Eugene D. 2005. "What Causes Democracy?" Center on Democracy, Development, and the Rule of Law (CDDRL) Working Papers, no. 38, Stanford Institute on International Studies.

[42] Mazur, Robert E. 2004. "Realization or Deprivation of the Right to Development Under Globalization? Debt, Structural Adjustment, and Poverty Reduction Programs." GeoJournal 60: 61-71.

[43] Ndulu, Benno J., and Stephen A. O'Connel. 1999. "Governance and Growth in Sub-Saharan Africa." Journal of Economic Perspectives 13(3): 41-66.

[44] Nkrumah, Gamal. 1998. "Battling Africa's Colonial Legacy." Al-Ahram Weekly 381.

[45] Przeworski, Adam, Michael E. Alvarez, José Antonio Cheilub, Fernando Limongi. 2000. Democracy and Well Being in the World 1950-1990. New York: Cambridge University Press.

[46] Przeworski, Adam, Michael E. Alvarez, José Antonio Cheilub, Fernando Limongi. 1996. "What Makes Democracies Endure." Journal of Democracy 7(1): 39-55.

[47] Robinson, James A. 2006. "Economic Development and Democracy." Annual Review of Political Science 9: 503-527.
[48] Robinson, James A. 1998. "Theories of Bad Policy." Policy Reform 1: 1-46.

[49] Rakotoarisoa, Jean-Aimé. 2002. "Les Racines Culturelles de la Crise Malgache." Le Monde Diplomatique 22.

[50] Ruscio, Alain. 2008. "Au Service du Colonisateur." Le Monde Diplomatique 3.

[51] Sanders, Edmund. 2008. "Democracy is losing Ground in Africa." Los Angeles Times, July 13.

[52] Sachs, Jeffrey D., and Andrew Warner. 1995. "Natural Resource Abundance and Economic Growth." National Bureau of Economic Research (NBER) Working Paper no. 5398.

[53] UNCTAD. 2007. Handbook of Statistics. Geneva: Developing Countries in International Trade Studies. www.unctad. org/en/docs/tdstat31ch3_enfr.pdf (Accessed November 2019)

[54] UNCTAD. 2005. Developing Countries in International Trade. Geneva: Developing Countries in International Trade Studies.

[55] UNDP. 2004. Human Development Report: Cultural Liberty in Today's Diverse World. Oxford: Oxford University Press.

[56] UNDP. 2002. Human Development Report: deepening democracy in a fragmented world. Oxford: Oxford University Press.

[57] Weber, Max. (1905) 1958. The Protestantism Ethic and the Spirit of Capitalism. Chicago: Scribner's Sons.

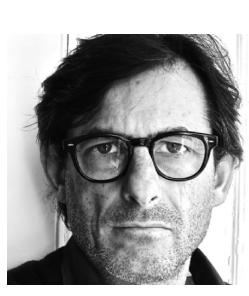

Manuel Couret Branco is a Full Professor of the Department of Economics of University of Évora and is an integrated member of the Research Center in Political Science. Manuel Couret Branco holds a Ph.D. in Economics (1988) and a Masters Degree in Economic Analysis and Policy (1983) both from the École des Hautes Études en Sciences Sociales, Paris, France. 